\title{
Black Soldier Fly (Hermitia illucens) Larvae Meal as Alter- native Protein in Broiler Production in Ghana
}

\author{
S. AFFEDZIE-OBRESI*, G. ADU-ABOAGYE, E.K. NKEGBE, N. ASUMING- \\ BEDIAKO, K.O. ANSAH, A. MENSAH-BONSU, D.B. SARPONG, D.P.K. AMEGASHIE, \\ G.T-M. KWADZO, P.A. WALLACE \& V.A. CLOTTEY \\ (S.A-O, G.A-A, E.K.N, N.A-B, K.O.A \& P.A.W.: CSIR Animal Research Institute P. O. Box AH \\ 20 Achimota, Accra ; A.M-B, D.B.S, D.P.K.A \& G.T-M.K.: Department of Agric Economics \\ and Agribusiness, University of Ghana, Legon, Accra ; V.A.C.: CABI West Africa Centre, P. \\ O. Box CT860 Cantonment Accra)
}

*Corresponding author's email: obresis@yahoo.com

\begin{abstract}
Feed cost has been a major challenge to the competitiveness of the poultry industry of Ghana due mainly to high cost of proteins. Insect larvae meals seem convenient alternatives however their use on commercial scale is unknown in Ghana. Three 8-week feeding trial using three isonitrogenous, isocaloric diets in a three-phase feeding strategy involving 1320 broiler DOCs was conducted. BSFLM was used as replacement for fishmeal and as partial replacement for soybean meal to determine its effect on broiler productivity, profitability and carcass measurements. The results indicated that replacing fishmeal with BSFLM significantly improved weight gain, feed conversion efficiency and production efficiency factor (PEF). No detrimental effect was observed on carcass and specific organ measurements. Using the partial budgeting approach on a 500-bird estimation an increase of one thousand, one hundred and eleven Ghana cedis $(\mathrm{GHC1} 1111.00)$ was obtained when the fishmeal was replaced with BSFLM. Also, an increase of four hundred and sixty-seven Ghana cedis (GHC467.00) was estimated when soybean meal was partially replaced with BSFLM. It was concluded that BSFLM can be used to improve the productivity and profitability of broiler production.
\end{abstract}

Keywords: Productivity; Profitability; Feed; Nutrition; Insect as Feed; Black Soldier Fly Original scientific paper. Received 29 Jul 2019; revised 18 Jan 2020

\section{Introduction}

Poultry worldwide is raised to provide food (meat and eggs), employment, manure and income (FAOSTAT, 2016). Being among the most commonly consumed animal-sourced foods and also the most accepted in most cultures, the poultry sector has become the fastest-growing enterprise within the animal subsector in the world (Alexandratos \& Bruisma, 2012). This increasing demand is corroborated by the Food and Agriculture Organisation (FAO) who projected a $58 \%$ to $70 \%$ increase in demand for meat and dairy products by the year 2050 (FAO, 2011). One of the possible ways of meeting the increasing demand is through intensification of the poultry

Ghana Jnl Agric. Sci. 55 (1), 1 - 13

GJAS is an Open Access Journal and distributed under the terms of the Creative Commons (CC) License [CC BY 4.0] 
production systems. This system, though efficient, requires a continuous supply of good quality feeds. However, conventionally known poultry feed ingredients such as maize, soybean and fishmeal are also major food items in human nutrition. Thus, the increasing human population would mean increasing demand for poultry products and subsequently increasing demand for maize, soybean and fishmeal.

Feeding poultry has become a major challenge to the industry, especially in the developing world. The high cost of feeding has made the locally produced broiler chicken less competitive against imported types (Willems et al., 2013; Waller, 2007; Okai et al., 2005; Omole, 2005). One critical nutrient in poultry feeds is protein which is conventionally supplied by fishmeal and soybean. The soybean meal (plant protein) which happens to be cheaper than fishmeal, is reported to have limited levels of methionine, lysine and threonine (essential amino acids) (Jozefiak et al., 2016) and may not adequately replace fishmeal without adequate supplementation with synthetic forms of these essential amino acids. However, the use of synthetic amino acids increases Ghana's demand for foreign exchange. Also, the use of fishmeal and soybean has become ecologically and economically unsustainable (Barona et al., 2010 and FAO, 2012) because the natural fish resources are overexploited (Frid \& Paramor, 2012) and again aquaculture requires high amounts of fishmeal and soybean (Bene et al., 2015). This worsens the supply and price of fish meal. There is, therefore, the need to identify cheaper, rich and safe sources of alternative proteins for poultry production in Ghana.

The use of insects and their larvae as animal feed ingredient is being promoted in many African countries (Pomalégni et al., 2017; Barre et al., 2014) as an alternative protein with the potential to increase the competitiveness of the poultry production. Insects have made significant contributions to animal production as feed ingredient; having been natural food for the wild fish and scavenging poultry (Bovera et al., 2015; Charlton et al., 2015). For instance, the use of termites in poultry production has existed for a long time in the rural or indigenous systems (Bovera et al., 2015; Charlton et al., 2015; Belluco et al., 2013; van der Spiegel et al., 2013; Hem et al., 2008; Newton et al., 2005b; and Calvert et al., 1969). The biological efficacy of insect proteins in poultry nutrition has been reported for termites (Diawara, 2013), housefly larvae (Dankwa et al., 2002) and BSFLM (Charlton et al., 2015; Kenis et al., 2014). However, the use of black soldier fly larvae meal (BSFLM) as an economically convenient alternative protein for commercial poultry production in Ghana requires investigation.

The black soldier fly (BSF), (Hermitia. Illucens) is a diptera fly of the Stratiomyidae family that is native to the Americas but now widespread throughout the tropical and temperate regions (Sheppard et al., 1994) being tolerant to a wide range of environments (Gujarathi \& Pajaver, 2013; Martinez-Sanchez et al., 2011) and amenable to mass production under intensive systems to produce larvae meal and to process organic waste. The black soldier fly larvae meal (BSFLM) is a good quality feed ingredient. It has high Metabolizable energy $(20-24 \mathrm{MJ} / \mathrm{Kg})$ and crude protein $(38.0 \%$ - 60.4\%) comparable to fishmeal $(60.5 \%$ - 65\%) and soybean (42.0\% - 47\%) and about 90\% digestible (Arango Gutierrez et al., 2004). It is a safe product that contains natural anti-microbial polypeptides (AMPs) to control infections or diseases (Ushakova et al., 2016). However, information on the effect 
of BSFLM on the cost of poultry feed, broiler growth performance, carcass characteristics and profitability of broiler production in Ghana is limited.

This study was conducted to assess the effect of BSFLM inclusion in broiler feeds on broiler productivity and profitability in Ghana. Specifically, the study assessed the effect of the inclusion of BSFLM on the cost of broiler feeds, broiler productivity, carcass characteristics and profitability. This study shows the potential of larvae meals as alternative protein source for poultry production and adds to evidence for policymakers to consider insect larvae meals as ingredient in animal feeds in Ghana.

\section{Materials and Methods}

Experimental Site

The feeding trials were conducted at the CSIRAnimal Research Institute, Pokuase Station. The station is located on longitude $0^{\circ} 16^{\prime} 59^{\prime \prime} \mathrm{W}$ and Latitude $05^{\circ} 40^{\prime} 59^{\prime \prime} \mathrm{N}$ in the coastal savannah ecological zone. The experiments were conducted from October, 2017 to June, 2018. The temperature and rainfall ranges for the period were $18^{\circ} \mathrm{C}-36^{\circ} \mathrm{C}$ and $20 \mathrm{~mm}-240$ $\mathrm{mm}$ respectively.

\section{Feed formulation}

Three isocaloric and isonitrogenous broiler diets were compounded to conform to the nutrient specifications of NRC (1994): Starter diets of 22-23\% crude protein/11-12 MJ Metabolizable energy, Grower diet of 20-21\% crude protein/11-12 MJ Metabolizable energy and Finisher diets containing 18-19\% crude protein/11-12 MJ Metabolizable energy were used for the experiments. Treatment 1 (T1) contained soybean meal as the sole source of protein. Treatment 2 (T2) contained a combination of soybean and fishmeal while in Treatment 3 (T3) the fishmeal component was completely replaced with the black soldier fly larvae meal. The fishmeal components were $8 \%$ in the starter, $5 \%$ in the grower and $2 \%$ in the finisher diets. Details of the feed formulation and costs for the trials are shown in Table 1.

TABLE 1

Composition of Diets for Starter, Grower and Finisher Stages of Broiler Birds

\begin{tabular}{|c|c|c|c|c|c|c|c|c|c|}
\hline \multirow[b]{2}{*}{ Ingredient Composition } & \multicolumn{3}{|c|}{ Starter Diet } & \multicolumn{3}{|c|}{ Grower Diet } & \multicolumn{3}{|c|}{ Finisher Diet } \\
\hline & $\begin{array}{l}\text { SBMDiet } \\
\text { (T1) }\end{array}$ & $\begin{array}{l}\text { Fish } \\
\text { Diet } \\
(T 2)\end{array}$ & $\begin{array}{l}\text { BSF } \\
\text { Diet } \\
\text { (T3) }\end{array}$ & $\begin{array}{l}\text { SBM } \\
\text { Diet } \\
(T 1)\end{array}$ & $\begin{array}{l}\text { Fish Diet } \\
\text { (T2) }\end{array}$ & $\begin{array}{l}\text { BSF } \\
\text { Diet } \\
\text { (T3) }\end{array}$ & $\begin{array}{l}\text { SBM } \\
\text { Diet } \\
(T 1)\end{array}$ & $\begin{array}{l}\text { Fish } \\
\text { Diet } \\
(T 1)\end{array}$ & $\begin{array}{l}\text { BSF Diet } \\
(T 2)\end{array}$ \\
\hline Maize & 58.45 & 61.50 & 52.30 & 59.50 & 62.15 & 53.50 & 62.05 & 65.00 & 58.0 \\
\hline Wheat bran & 0.00 & 2.00 & 0.00 & 2.50 & 2.50 & 4.00 & 7.00 & 5.00 & 10.0 \\
\hline Soybean meal & 37.15 & 24.70 & 35.65 & 33.55 & 26.00 & 33.00 & 27.00 & 25.00 & 26.05 \\
\hline Fishmeal & 0.00 & 8.00 & 0.00 & 0.00 & 5.00 & 0.00 & 0.00 & 2.00 & 0.00 \\
\hline BSFLM & 0.00 & 0.00 & 8.00 & 0.00 & 0.00 & 5.00 & 0.00 & 0.00 & 2.0 \\
\hline Lysine & 0.30 & 0.25 & 0.25 & 0.20 & 0.20 & 0.20 & 0.20 & 0.25 & 0.2 \\
\hline Methionine & 0.05 & 0.00 & 0.00 & 0.10 & 0.10 & 0.10 & 0.10 & 0.10 & 0.1 \\
\hline Dicalcium phosphate & 1.40 & 1.00 & 1.30 & 1.00 & 1.00 & 1.00 & 1.00 & 1.00 & 1.0 \\
\hline Oyster shell & 1.50 & 1.50 & 1.50 & 2.00 & 2.00 & 2.00 & 2.00 & 2.00 & 2.0 \\
\hline Salt & 0.35 & 0.25 & 0.20 & 0.35 & 0.25 & 0.40 & 0.35 & 0.30 & 0.35 \\
\hline Min/vit premix & 0.30 & 0.30 & 0.30 & 0.30 & 0.30 & 0.30 & 0.25 & 0.25 & 0.25 \\
\hline Avatec feed additive & 0.50 & 0.50 & 0.50 & 0.50 & 0.50 & 0.50 & 0.10 & 0.10 & 0.10 \\
\hline Calculated Analysis & & & & & & & & & \\
\hline ME (MJ/Kg) & 11.52 & 11.99 & 11.45 & 11.54 & 11.81 & 11.35 & 11.49 & 11.78 & 11.27 \\
\hline Crude Protein $(\%)$ & 22,13 & 22.32 & 21.68 & 21.02 & 21.11 & 21.05 & 19.02 & 19.00 & 18.96 \\
\hline Crude Fibre (\%) & 2.74 & 2.56 & 2.78 & 2.78 & 2.63 & 3.04 & 3.06 & 3.04 & 3.39 \\
\hline
\end{tabular}


The costs $(\mathrm{C})$ of the experimental diets were computed using the market prices of the ingredients as the sum of the products of the quantities $\left(\mathrm{q}_{\mathrm{i}}\right)$ of ingredient ' $i$ ' in the formulation and their prices $\left(\mathrm{p}_{\mathrm{i}}\right)$. This was specified as

$$
C=\sum p_{i} X q_{i}
$$

\section{Experimental design}

Three feeding trials were conducted to determine the effect of BSFLM substitution and season of rearing on broiler chicken performance. The first trial was conducted between October-December, 2017 which was the onset of the dry season. The second was done in January- March, 2018 representing the major dry season and the third was conducted from April -June, 2018, representing the major rainy season. Each of the experiments lasted for eight weeks to conform to the conventional broiler growing period in Ghana.

A total of 1320 Cobb broiler day-old chicks were used in the three feeding trials. In the first trial (October-December, 2017), 480 day-old chicks were tagged, weighed and distributed among the three treatments. Each treatment was replicated four times with 40 birds per replicate. The same number of treatments, replicates and birds were repeated for the second trial. In the third trial, 360 chicks were used due to inadequate number of chicks. The three treatments and the number of birds (40) per replicate were maintained but the number of replicates was reduced to three. In all trials, the Complete Randomised Design (CRD) was used.

The recommended feeding regime of The National Research Council (NRC) (1994) namely; three weeks for Starter diet, three weeks for Grower diet and two weeks for Finisher diet, was used for the experimentation.
The birds were allowed free access to feed and water in deep litter cubicles allowing a stocking rate of $15 \mathrm{birds} / \mathrm{m}^{2}$ for the adults. Prophylactic treatment schedule prescribed by the Veterinary Service Department (VSD) of Ghana was duly followed.

\section{Parameters monitored}

The birds and feed were weighed weekly and used to determine weight gain and feed intake while mortalities were recorded daily. Weight gain was determined as the increase in body weight. Feed intake was determined as the difference in the weight of feed offered and feed leftover. Feed productivity or feed conversion ratio (FCR) was determined as the ratio of feed intake (FI) to weight gain (WG). Feed cost (FC) was calculated as the product of feed intake (FI) and unit price of the feed (P). Bird liveability or survivability (L) was computed using the formula of Abdurofi et al., (2016) as;

$$
L=100\left(\frac{n}{N}\right)
$$

Where ' $n$ ' is the number of birds alive at the end of the experiment and ' $\mathrm{N}$ ' is the initial number of birds used

The production efficiency factor (PEF) was computed using the formula prescribed by Ross Broiler Management (2009) and expressed as:

$$
P E F=100 \frac{L * B W t}{D * F C R}
$$

where ' $L$ ' denotes liveability or survival rate; ' $B W t$ ' denotes liveweight of bird at slaughter (average live weight of birds at $8^{\text {th }}$ week); ' $D$ ' refers to the number of days taken to reach slaughter or market weight and $F C R$ refers to feed conversion ratio estimated by Abdurofi et al., (2016). 
In determining the effect of the dietary treatment on the carcass characteristics four birds (two females and two males) were randomly selected from each replicate at the end of the experimental period. These birds were slaughtered by severing the jugular vein and selected parameters namely blood, feathers, organs (liver, spleen, and heart) and carcass weights were measured and expressed as a percentage of the liveweight.

Data on the growth and carcass parameters were subjected to analysis of variance using GENSTAT 11 Analytical software. The differences in means were partitioned using the Least Significant Difference (LSD) test. The partial budgeting technique was used to compare the financial benefits of adopting BSFLM-containing feeding technology over the conventional proteins sources. Broiler production costs were categorised into feed cost (FC) and other costs (OC) while revenues were computed as the product of the liveweight at end of the experiment and market price of GHS12.00 per kilogram.

\section{Results}

Effect of BSFLM Inclusion on the Cost of Broiler Feeds

Results of the effect of BSFLM inclusion on the cost of the various diets are shown in Table 2 . There were significant differences in the cost of the Starter and Grower diets. However, the Finisher diets showed a significant increase in the cost of the fishmeal-containing (T2) diet while the cost of soybean (T1) and the BSFLMcontaining (T3) diets was similar. The results indicate that using soybean as sole protein (T1) gave the cheapest feed followed by the BSFLM containing diet (T3). The fishmeal-containing diet (T2) was the most expensive. It was noted that partial replacement of the soybean with BSFLM significantly increased the cost of the Starter and the Grower diets but not the Finisher diet. However partial replacement of soybean with fishmeal significantly increased the cost of all feed types. Subsequently, the replacement of the fishmeal with BSFLM significantly reduced the cost of all the feed types (Table 2).

TABLE 2

Effect of Replacing Soybean and Fishmeal with BSFLM on Broiler Feed Cost

\begin{tabular}{|c|c|c|c|c|c|}
\hline Feed Type & $\begin{array}{l}\text { Soybean Meal (GHS/ } \\
\text { kg) (T1) }\end{array}$ & $\begin{array}{l}\text { Fishmeal } \\
(T 2)\end{array}$ & (GHS/kg) & BSFLM (GHS/kg) (T3) & SEM \\
\hline Starter & $2.02^{\mathrm{a}}$ & $2.22^{\mathrm{c}}$ & & $2.07^{\mathrm{b}}$ & 0.01502 \\
\hline Grower & $1.96^{\mathrm{a}}$ & $2.18^{\mathrm{c}}$ & & $2.00^{\mathrm{b}}$ & 0.01691 \\
\hline Finisher & $1.70^{\mathrm{a}}$ & $1.82^{\mathrm{b}}$ & & $1.70^{\mathrm{a}}$ & 0.01000 \\
\hline
\end{tabular}

NB: Means in a row with same or no superscript are not significantly different

$\$ 1.00=$ GHS5.00 
Effect of Substituting Fishmeal with BSFLM on Broiler Chicken Productivity

The effect of the dietary treatment on broiler growth and productivity are presented in Table

3. The dietary treatment had a significant
$(\mathrm{P}<0.05)$ effect on mature body weight, weight gain and feed conversion ratio but did not significantly $(\mathrm{P}>0.05)$ affect the survivability of the birds.

TABLE 3

Effect of Dietary Treatment on Broiler Chicken Productivity

\begin{tabular}{lllll}
\hline Parameter & $\begin{array}{l}\text { SBM } \\
(\boldsymbol{T 1})\end{array}$ & $\begin{array}{l}\text { Fishmeal } \\
(\boldsymbol{T} 2)\end{array}$ & $\begin{array}{l}\text { BSFLM } \\
(\boldsymbol{T} 3)\end{array}$ & SEM \\
& 40.64 & 40.27 & 40.55 & \\
\hline Initial body weight (g/bird) & 5212.97 & 5175.36 & 5165.12 & 8.1328 \\
Total Feed intake (g/bird) & $2149.00^{\mathrm{ab}}$ & $2081.00^{\mathrm{a}}$ & $2186.00^{\mathrm{b}}$ & 22.000 \\
Mature body weight (g/bird) & $2107.80^{\mathrm{ab}}$ & $2040.28^{\mathrm{a}}$ & $2145.63^{\mathrm{b}}$ & 22.089 \\
Weight gain (g/bird) & 2.48 & 2.54 & 2.41 & 0.040 \\
Feed conversion ratio & 87.58 & 88.19 & 90.68 & 1.482 \\
Liveability (\%) & $136.97^{\mathrm{ab}}$ & $129.75^{\mathrm{a}}$ & $147.15^{\mathrm{b}}$ & 4.345 \\
Prod. Efficiency Factor & $9.68^{\mathrm{a}}$ & $10.50^{\mathrm{b}}$ & $9.71^{\mathrm{a}}$ & 0.160 \\
Feed cost per bird (GHS) &
\end{tabular}

NB: Means in a row with same or no superscript are not significantly different.

The quantity of feed (in grams) consumed by a bird over the study period (eight weeks) is shown in Table 3. The average feed intakes were $5,212.97 \mathrm{~g}(5.2 \mathrm{~kg})$ for birds on soybeandiet (T1), 5,175.36 g (5.2 kg) for those on fishmeal-containing diet (T2) and 5,165.12 g $(5.2 \mathrm{~kg})$ for those on BSFLM-containing diet (T3). The dietary treatment did not have any significant $(\mathrm{P}>0.05)$ effect on feed intake even though feed intake tended to be highest for the soybean diet (T1) and least for BSFLMcontaining diet (T3).

The dietary treatment significantly affected the mature live weight of birds which translated into weight gains. It was observed that birds on fishmeal-containing diets (T2) had the least weight gain of $2,040.28 \mathrm{~g}(2.04 \mathrm{~kg})$ while birds that were fed BSFLM-containing diet (T3) had significantly higher weight gain of $2,145.63 \mathrm{~g}(2.15 \mathrm{~kg})$. However, the difference between the weights gains of birds that were fed with only soybean diet (T1) and those fed BSFLM-containing diets (T3) was not significant $(\mathrm{P}>0.05)$ (Table 3 ).

The feed conversion ratio (FCR) describes the rate at which feed is converted into body weight. The FCR was 2.48 for soybean diet (T1), 2.54 for fishmeal-containing $\operatorname{diet}$ (T2) and 2.41 for BSFLM-containing feed (T3). The dietary treatment did not significantly $(\mathrm{P}>0.05)$ affected the FCR (T3).

Liveability refers to the ratio of the number of surviving birds at the end of the experimentation to the initial number of birds. The results showed numerical increase in survivability when fishmeal and BSFLM were included in the diets however the increases were not statistically different $(\mathrm{P}>0.05)$.

The feed costs for producing a broiler chicken were GHC9.68 for soybean diet (T1), GHC10.50 for fishmeal-containing diet (T2) and GHC9.71 for BSFLM-containing diet (T3). The differences among the means were significantly different $(\mathrm{P}<0.05) \quad$ (Table 3) 
thus it is more expensive to produce broilers with fishmeal diet (T2). The study recorded Production Efficiency Factor (PEF) values of 136.97 for pure soybean diet (T1), 129.75 for fishmeal-containing diet (T2) and 147.15 for BSFLM-containing diet, which are statistically different $(\mathrm{P}<0.05)$.

The results from the analysis of the seasonal effect on the bird performance showed no significant differences indicating that the seasons had no serious effect on bird performance.

\section{Effect of Dietary Treatment on Carcase Measurements}

The effect of dietary treatment on broiler carcass measurements is presented in Table 4. The results indicated that all carcass characteristics except the liver, gizzard and neck were not significantly $(\mathrm{P}>0.05)$ affected by the dietary treatment. The liver of bird fed fishmeal-containing diet (T2) was $1.95 \%$ of the live weight of a bird. This was significantly higher than $1.74 \%$ and $1.75 \%$ recorded for birds fed soybean (T1) and BSFLM-containing (T3) diets respectively. The gizzard weight of birds fed with fishmeal-containing diets (T2) was $1.43 \%$ of the live weight of a bird. This was significantly lower than $1.61 \%$ recorded for birds that were fed with soybean (T1) or BSFLM-containing (T3) diets. The neck was significantly lower for birds that were fed with fishmeal-containing (T2) diets.

TABLE 4

Effect of Dietary Treatment on Broiler Carcass Measurements

\begin{tabular}{lllll}
\hline Parameter & $\begin{array}{l}\text { Soybean } \\
\text { Meal (T1) }\end{array}$ & Fishmeal (T3) & BSFLM (T2) & SEM \\
& 3.60 & 4.59 & 3.71 & \\
\hline Blood \% & 7.76 & 8.38 & 7.70 & 0.2157 \\
Feather (\%) & 67.69 & 65.98 & 67.11 & 0.2338 \\
Edible carcass (\%) & $1.74^{\mathrm{a}}$ & $1.95^{\mathrm{b}}$ & $1.75^{\mathrm{a}}$ & 0.4236 \\
Liver (\%) & 0.06 & 0.05 & 0.05 & 0.0400 \\
Spleen (\%) & $1.61^{\mathrm{b}}$ & $1.43^{\mathrm{a}}$ & $1.61^{\mathrm{b}}$ & 0.0029 \\
Gizzard (\%) & 5.63 & 5.85 & 5.50 & 0.0298 \\
Intestine (\%) & 0.63 & 0.64 & 0.59 & 0.1267 \\
Heart (\%) & 4.32 & 4.44 & 4.51 & 0.0218 \\
Shank (\%) & 2.54 & 2.49 & 2.58 & 0.1041 \\
Head (\%) & $5.74^{\mathrm{b}}$ & $5.17^{\mathrm{a}}$ & $5.52^{\mathrm{ab}}$ & 0.0402 \\
Neck (\%) & & & 0.0814 \\
\hline
\end{tabular}

NB: Means in a row with same or no superscript are not significantly different.

Partial Budget Estimation for a Batch Production of 500 Broilers

The result of the partial budget estimation of the profitability of replacing fishmeal with BSFLM is presented in Table 5. The bird numbers were adjusted for mortality and assumed a market price of GHC12.00 per kilogram live-weight of bird. The estimated cost of feeding a batch of 500 birds was GHC5,421.07 \pm GHC 324.92 for fishmeal-containing diet (T2) while that for BSFLM (T3) was GHC5, 132.24 \pm GHC147.19. The estimated revenue from using T2 diet for that batch (accounting for mortality) was 
GHC11,066.74 \pm GHC1,081.23 while using (T3) diet was GHC11,888.94 \pm GHC312.07. The partial budget analysis indicates that farmers are likely to obtain a net gain of GHC1,111.00 by replacing fishmeal with black soldier fly larvae meal in feed to produce 500 broiler chickens (Table 5).

TABLE 5

\begin{tabular}{|c|c|c|c|}
\hline \multicolumn{4}{|c|}{ Partial Budget for Replacing Fishmeal with BSFLM in Producing 500 Broilers } \\
\hline (GHS) & & Losses (GHS) & \\
\hline New Income & & Revenue forgone & \\
\hline Value of chicken (BSF) & $11,888.94$ & Value of chicken (fish) & $11,066.74$ \\
\hline Cost forgone & & New Cost & \\
\hline Cost of fishmeal feed & $5,421.07$ & Cost of BSF feed & $5,132.24$ \\
\hline Other costs & $3,424.02$ & Other costs & $3,424.02$ \\
\hline Total Gains & $20,734.03$ & Total Loss & $19,623.00$ \\
\hline Net Gain & $1,111.03$ & & \\
\hline \multicolumn{2}{|c|}{$\begin{array}{l}\text { The result of the partial budget for including } \\
\text { BSFLM (T3) as partial replacement of soybean } \\
\text { (T1) is shown in Table } 6 \text {. The cost of feeding } \\
\text { BSFLM diet (T3) remained the same as } \\
\text { above however the cost of the soybean was }\end{array}$} & \multicolumn{2}{|c|}{$\begin{array}{l}\text { GHC } 5,130.73 \text { and the value of chicken raised } \\
\text { on soybean diet was GHC } 11,420.36 \text {. This } \\
\text { yields an estimated net gain of GHC } 467.07 \\
\text { indicating that inclusion of BSFLM as partial } \\
\text { replacement of soybean in broiler diets is better. }\end{array}$} \\
\hline \multicolumn{4}{|c|}{ TABLE 6} \\
\hline \multicolumn{4}{|c|}{ Partial Budget for Including BSFLM in Soybean Diet Producing 500 Broilers } \\
\hline$\overline{\text { Gains }}$ & & Losses & \\
\hline New Income & & Revenue Forgone & \\
\hline Value of chicken & $11,888.94$ & Value of Chicken (soybean) & $11,420.36$ \\
\hline Cost Forgone & & New Cost & \\
\hline Cost of soybean feed & $5,130.73$ & Cost of BSFLM feed & 5.132 .24 \\
\hline Other costs & $3,424.02$ & Other costs & $3,424.02$ \\
\hline Total Gains & $20,443.69$ & Total Loss & $19,976.62$ \\
\hline Net Gain & 467.07 & & \\
\hline
\end{tabular}

The results showed that the feeds without animal (only vegetable) protein was cheaper than those containing animal proteins (fishmeal and BSFLM) (Table 2). This is because the price of soybean (GHC3.10) was the cheapest protein available while that of BSFLM and fishmeal were GHC3.22 and GHC6.00 respectively. It can be inferred that fishmeal significantly increased the cost of feed and its replacement with soybean or BSFLM is a better option at reducing the cost of feed. The replacement of fishmeal with BSFLM significantly reduced the cost of the feed types. The result showed that the prices of the ingredients correlate with the cost of feed and vegetable proteins of lower prices can be used to formulate feeds of comparative quality at lower costs. However, low-cost feeds may not necessarily lead to increased profitability.

\section{Discussion}

The performance of the birds on the dietary treatments showed that the best growth rate was obtained from birds that were fed BSFLM- 
containing diets (T3) (Table 3). This result is consistent with an earlier study by Dankwa et al., (2002) that housefly larvae meal increased the body weight gains of broilers. The findings of this study are also consistent with the findings of Jozefiak et al. (2016) that black soldier fly larvae meal can conveniently replace soybean meal. The observed high growth rate was probably due to improved digestibility of the diets as a result of the digestibility of BSFLM (Arango Guttierez et al., 2014). The increased growth rate could also be influenced by higher fibre content which slows down feed passage to increase gizzard activity to aid digestion and also lower gizzard and digesta $\mathrm{pH}$ to stimulate pepsin and protein digestion (Dunkley, 2007). The improved digestibility of the feed made nutrients available for use by the birds.

It was also observed that the FCR was numerically best for BSFLM-containing diet (2.41) and worst for fishmeal-containing diet (2.54). The FCR values obtained in the study were similar to 2.4-2.6 report by Attoh-Kotoku et al. (2010) when they included Annato (Bixa orellana) leaves in broiler diets. The FCR values in this study were however higher than 2 which, according to Abdurofi et al., (2016), reduces profitability. The inclusion of BSFLM in feed slightly tended to improve FCR and could improve profitability. The improvement in feed conversion ratio translated into body weight gain which is attributable to the availability of nutrients as a result of improved digestibility of the larvae meal (Arango Gutierrez et al., 2014).

The Production Efficiency Factor (PEF), a composite indicator of husbandry efficiency, was best with the inclusion of BSFLM. Fishmeal-containing diet (T2) had the worst (PEF) value. This is expected because the fish-containing diet (T2) had the worst FCR, body weight gain and the least liveability. The improvement in the PEF for birds that were fed BSFLM-containing diet (T3) could be due to the improvement in feed productivity (FCR) as a result of improved digestibility, improved growth rate due to availability of nutrients and the anti-microbial agents (antimicrobial peptides) in the larvae meal that might have helped to control pathogen proliferation and improved liveability. The values obtained were lower than the European accepted range of 200 - 225 (Szöllösi et al., 2014). This means that the husbandry practices were not as efficient as that expected of the Europeans. There is, therefore, the need to improve husbandry efficiency to increase profitability and competitiveness.

Dietary treatment significantly affected feeding costs. Even though the vegetable feeds (Starter, Grower and Finisher) were the cheapest, they did not result in lowest feeding cost because they were unable to support the high growth rate. The profitability of broiler production is associated with feed conversion efficiency (Abdurofi et al., 2016) which also correlates with feed quality (Waller, 2007; Nworgu \& Egbunike, 2000). Since the productivity and profitability of broiler production depend on feed quality and cost, attention must be paid to the nutrient quality, digestibility and cost of the ingredients. The lowered feed cost and better feed utilisation were responsible for the improved profitability of the BSFLM-containing diet (T3).

The dietary treatment did not have significant effect on majority of the carcass measurements such as blood, feathers, carcass yield, shank, head and some internal organs such as heart, spleen and intestines (Table 4). The results agreed with reports by Yusuf et al., (2015) that the use of rice milling waste did not significantly affect these organs. On the contrary, the liver, gizzard and neck in the present study 
showed significant changes. The liver was significantly higher in the fishmeal-containing diet (T2) than the vegetable (T1) and BSFLMcontaining (T3) diets. The fishmeal-containing diet might have put more stress (more work) on the liver resulting in an increase in its weight. Increased demand on organs causes the organ to develop (hypertrophy) to manage the stress. For example, it is reported that higher dietary fibre slows down feed passage and increases digestion causing physical distension and concomitant increase in size and capacity of the gastrointestinal tract (Sacranie et al., 2012; Jorgensen et al., 1996). This explains why the gizzards of the T1 and T3 were significantly heavier than that of $\mathrm{T} 2$ as these diets had relatively higher crude fibre content (Table 1). There were significant differences in the mean weight of the neck which can also be ascribed to the effect of the fibre content of the diets in the oesophagus and the crop.

The partial budget analysis is based on the principle that a change in the course of action is deemed beneficial if there is a gain after total cost associated with the change (Losses) is subtracted from the associated total benefits (Gains) (Lessley et al., 1991). In practice, the partial budgeting technique weighs the quantum of gains to be obtained in adopting the black soldier fly larvae meal technology against the costs or losses in doing so. The findings indicated that replacing fishmeal with BSFLM yielded a gain of one thousand, one hundred and eleven Ghana cedis $(\mathrm{GHC} 1,111.00)$ (Table 5 ) while partial budget for partially replacing soybean meal with BSFLM also led to a gain of four hundred and sixty-seven Ghana cedis (GHC467.00) (Table 6) for a batch of 500 broilers. The gains were due to the improved weight gain, improved survivability and improved feed utilisation associated with the use of BSFLM. The findings suggest that reduced feed cost, improved survivability, increased feed utilisation, and higher market weight of birds translated to financial gains exhibited in partial budget analyses in Tables 5 and 6.

\section{Conclusion and Recommendations}

The results of the study show that the inclusions of black soldier fly larvae meal either as replacement for fishmeal or as partial replacement for soybean meal resulted in significant reduction in the cost of broiler feeds (Starter, Grower and Finisher) and total feed cost in broiler production. It also improved broiler growth, survivability and productivity and did not have any detrimental effect on the broiler carcass measurements. The partial budget analyses indicated that it is financial beneficial for broiler farmers to adopt BSFLM as protein source to be incorporated alongside soybean meal. It can be concluded that black soldier fly larvae meal is a good alternative protein ingredient that can be used to replace fishmeal but must be used in combination with soybean in broiler diets to improve the productivity and profitability of broiler production.

The authors make the following recommendations based on the findings of this study. It is recommended that;

1. Black soldier fly larvae meal should be used in combination with vegetable proteins

2. Black soldier fly larvae meal can be included at a rate of up to $10 \%$ in the broiler diets especially the Starter diets

3. Policy-makers should consider Black Soldier Fly larvae meal as approved feed ingredients in Ghana. 
4. Further studies should be carried out using layers and other livestock.

\section{REFERENCES}

Abdurofi, I., Ismail, M.M., Kamal, H. A. W. \& Gabdo, B. H. (2016) Economic Analysis of Broiler Production in Peninsular Malaysia. International Food Research Journal 24, 761 -766 .

Alexandratos, N., \& Bruisma, J. (2012) World Agriculture Towards 2030/2050: The 2012 Revision (No 12-03, p. 4). Rome, FAO: ESA Working Paper.

Arango Gutiérrez, G.P., Vergara Ruiz, R.A. \& Mejía Vélez, H. (2004) Compositional, microbiological and protein digestibility analysis of the larva meal of Hermetia illuscens L.(Diptera: Stratiomyidae) at Angelópolis-Antioquia, Colombia. Revista Facultad Nacional de Agronomía, Medellín 57, $2491-2500$.

Attoh-Kotoku, V., Atuahene, C.C., Afriyie, O.K.K., Arthur, E. A., \& Mensah, J. J. (2010) A preliminary Study of Annato (Bixa orellana) leaf meal in broiler chicken diets. In proceedings of the $28^{\text {th }}$ and $29^{\text {th }}$ Ghana Animal Science Association (GASA) conference.

Barre, A., Rougé, P., Caze-Subra, S., Gironde, C., Bienvenu, F. \& Bienvenu, J. (2014) Entomophagie et risque allergique. Revue Française d'Allergologie 4356, 287 - 343.

Barona, E., Ramankutty, N., Hyman, G. \& Coomes, O.T. (2010) The role of pasture and soybean in deforestation of the Brazilian Amazon. Environmental Research Letters 5, 024002.

Belluco, S., Losasso, C., Magiolleti, M., Alonzi, C. C., Paoletti, M. G. \& Ricci, A. (2013) Edible Insects in a Food Safety and Nutritional Perspective: A Critical Review. Comprehensive Reviews in Food Science and Food Safety 12, 296 - 313.
Bene, C., Barange, M., Subasinghe, R., PinstrupAnderson. P., Merino, G., Hemre, G-I., \& Williams, M. (2015) Feeding 9 billion by 2050-Putting fish back on the menu. Food Security 7, $261-274$.

Bosch, G., Zhang, S., Oonincx, D., \& Hendriks, W. H., (2014) Protein quality of insects as potential ingredients for dog and cat foods. Journal of Nutrition Science, 3, E29 doi:10,1017/jns.2014.23.

Bovera, F., Loponte, R., Marono, S., Piccolo, G., Parisi, G., Iaconisi, V., Gaco, L. \& Nizza, A. (2015) Use of Teneberio molitor larvae meal as protein source in broiler diet: Effect on growth performance, nutrient digestibility, and carcass and meat traits. Journal of Animal Science 94, 639-647.

Calvert, C.C., Martin, R.D. \& Morgan, N.O. (1969) House fly pupae as food for poultry. Journal of economic Entomology 62, 938 - 939.

Charlton, A. J., Dickinson, M., Wakefield, M. E., Fitches, E., Kenis, M., Han, R., Zhu, F., Kone, N., Grant, M., Devic, E., Bruggeman, G., Prior, R. \& Smith, R. (2015) Exploring the chemical safety of fly larvae as a source of protein for animal feed. Journal of Insect as Food and Feed 1 (1), 7 - 16.

Dankwa, D., Nelson, F. S., Oddoye, E. O. K., \& Duncan, J. L. (2002) Housefly Larvae as a Feed Supplement for Rural Poultry. Ghana Journal of Agricultural Science 35, 185 - 187.

Diawara, M. (2013) Impact the l'Utilisation des Termites en Aviculture Traditionelle au Burkina Faso. - Mémoire de Fin de Cycle. Université Polytechnique de Bobo-Dioulasso, Burkina Faso.

Dunkley, K. D., Dunkley, C. S., Njongmeta, N. L., Callaway T. R., Hume M. E., Kubena L. F., Nisbet D. J., \& Ricke S. C. (2007) Comparison of vitro fermentation and microbical profile of high-fiber feed substract 
incubated with chicken cecal inocula. Poultry Science 86, $801-810$.

Erickson, M. C., Islam, M., Sheppard, C., Liao, J. \& Doyle, M. P. (2004) Reduction of Escherichia coli O157:H7 and Salmonella enterica serovar enteritidis in chicken manure by larvae of the black soldier fly. Journal of Food Protection 67, $685-690$.

Food and Agriculture Organization Statistics (FAOSTAT) (2016) Statistical Database. FAO, Rome

Food and Agriculture Organisation (FAO) (2011) World Livestock 2011 - Livestock in Food Security. Food and Agriculture Organization of the United Nations (FAO), Rome.

Food and Agriculture Organisation (FAO) (2012) State of the World Fisheries. FAO, Rome.

Frid, C. L. J. \& Paramor, O. A. L. (2012) Feeding the World: What Role for Fisheries? ICES Journal of Marine Sciencel journal du Conseil 69, $145-150$.

\section{GENSTAT Release 11 (2008) (PC/Windows) VSN} International Ltd

Gujarathi, G. \& Pajaver, M. (2013) Occurrence of Black Soldier Fly (mmj Hermitia illucens) (Diptera: Stratiomyidae) in Biocompost. Research Journal of Recent Science 2, 65- 66.

Hem, S., Toure, S., Sagbla, C. \& Legendre, M. (2008) Bioconversion of palm kernel meal for aquaculture: Experiences from the forest region (Republic of Guinea). African Journal of Biotechnology 7, 1192 - 1198.

Jorgensen, H., Zhao, X. Q., Knudsen, K. E. B. \& Eggum, B. O. (1996) The Influence of Dietary Fibre Source and Level on the Development of the Gastrointestinal tract, Digestibility and Energy Metabolism in Broiler chickens. British Journal of Nutrition 15, 379 - 395.
Jozefiak, D., Jozefiak, A., Kieronczyk, B., Rawski, M., Swiatkiewicz, S., Dlugosz, J. \& Engberg, R. M. (2016) Insects-A Natural Nutrient Source for Poultry- A Review. Annals of Animal Science 16 (2), 297 - 313.

Kay, D. R., Edwards, M. W., \& Duffy, P. A. (2008) Farm Management. New York, McGraw Hill publication.

Kenis, M., Koné, N., Chrysostome, C.A.A.M., Devic, E., Koko, G.K.D., Clottey, V.A.,Nacambo, S., \& Mensah, G.A. (2014) Insects Used for Animal Feed in West Africa. Entomolgia 2 (2), $107-114$.

Lessley, B. V., Johnson, D. M., \& Hanson, J. C. (1991) Using the Partial Budget to Analyse Farm Change. University of Maryland Cooperative Extension Fact Sheet FS-547. Web page: http://www.agar.umd.edu/MCE/ Publications/PDFs/FS547.pdf. Accessed: April, 6, 2016

Lynch, M. \& Walsh, B. (1998) Genetics and Analysis of Quantitative traits. Sunderland, MA, Sinaeur Associates.

Makkar, H. P. S., Tran, G., Heuzé, V., \& Ankers, P. (2014) State-of-the-art on Use of Insects as Animal Feed. Animal Feed Science and Technology 197, 1 - 33. http://dx.doi. org/10.1016/j.anifeedsci.2014.07.008.

Martinez-Sanchez, A., Magana, C., Salona, M. \& Rojo, S. (2011) First record of Hermitia illucens (Dipteera: Stratiomyidae) on Human Corpses in Iberian Peninsula. Forensic Science International 206 (1), 76 - 78

National Research Council (NRC) (1994) Nutrient Requirements of Poultry $9^{\text {th }}$ Edition. National Academy Press, Washington, DC.

Newton, L., Sheppard, C., Watson, D. W., Burtle, G., \& Dove, R. (2005) Using the black soldier fly, Hermetia illucens, as a value-added tool for the management of swine manure. In: 
Report for Mike Williams, Director of Animal and Poultry Waste Management Centre. North Carolina State University. Available from www.cals.ncsu.edu/waste_mgt/smithfield projects/phase2report05/cd,web\%20files/ A2.pdf.

Nworgu, F. C. \& Egbunike, G. N. (2000) Performance and Nitrogen Utilization of Broiler Chicks Fed Full Fat Extruded Soybean Meal and Full Fat Soybean. Tropical Animal Production Investigation Journal 3, 47 - 54.

Okai, D. B., Abora, P. K. B., Davis, T. \& Martin, A. (2005) Nutrient Composition, Availability, Current and Potential Uses of "Dusa"; A Cereal By-product Obtained from "Koko" (porridge) Production. Journal of Science and Technology 25 (1), 33 - 38

Omole, A.J., Ogbosuka, G.E., Salako, R.A. \& Ajayi, O.O. (2005) Effect of Replacing Oyster Shell with Gypsum in Broiler Finisher Diet. - Journal of Applied Science Research 1 (2), $245-248$.

Pomalégni, S. C. B., Gbemavo, D. S. J. C., Kpadé, C. P., Kenis, M. \& Mensah, G. A. (2017) Traditional use of fly larvae by small poultry farmers in Benin. Journal of Insects as Food and Feed 3, 187 - 192.

Sacranie, A., Svihus, B., Denstadli, V., Moen, B., Iji, P. A., \& Chock, M. (2012) The Effect of Insoluble Fibre and intermittent feeding on gizzard development, gut motility and performance of broiler chickens. Poultry Science 91, 693 - 700

Shantibala, T., Lokeshwari, R. K., \& Debaraj, H. (2014) Nutritional and antinutritional composition of the five species of aquatic edible insects consumed in Manipur, India. Journal of Insect Science 14, 1 - 10.
Sheppard, D. C., Newton, G. L., Thompson, S. A. \& Savage, S. (1994) A value-added manure management system using the black soldier fly. Bioresource Technology 50, $275-279$.

Szőllősi, L., Szúcs, I., \& Nábrádi, A. (2014) Economic issues of broiler production length. Ekonomika Poljoprivrede 61 (3), 633 - 646.

Ushakova, N., Bastrakov, A., Kozlova, A., Ponomarev, S. Bakaneva, Y. M., Fedorovykh, Y. V., Zhandalgarova, A \& Pavlov, D. (2016) Features of the effect of a complex probiotic with Bacillus bacteria and the larvae of Hermitia illucens biomass on Mozambique tilapia (Oreochromis mossambicus x $\mathrm{O}$. niloticus) and Russian sturgeon (Acipenser gueldenstaedt). Biology Bulletin 43 (5), 450 $-456$

Van der Spiegel, M., Noordam, M. Y., \& Van der Fels-Klerx, H. J. (2013) Safety of novel protein sources (insects, microalgae, seaweed, duckweed, and rapeseed) and legislative aspects for their application in food and feed production. Comprehensive Reviews in Food Science and Food Safety 12, $662-678$.

Waller, A. (2007) Economic Approach to Broiler Production. Ross Tech Notes

Willems O. W., Miller S. P., \& Wood, B. J. (2013) Aspects of selection for feed efficiency in meat producing poultry, World's Poultry Science Journal 69 (1), 77 - 88.

Yusuf, M., Liman, A. A., Antyev, M., Faruk, A., Doma, U. D., Bello, K. M., Adamu, N. \& Muhammed, F. (2015) Carcass yield and gut characteristics of broiler chickens fed dietary levels of rice milling waste. ATBU, Journal of Science, Technology \& Education (JOSTE) 3 (4), 88 - 94 ISSN: 2277-0011. 